\title{
Cystine/glutamic acid transporter is a novel marker for predicting poor survival in patients with hepatocellular carcinoma
}

\author{
HIROKI KINOSHITA, HIROHISA OKABE, TORU BEPPU, AKIRA CHIKAMOTO, HIROMITSU HAYASHI, \\ KATSUNORI IMAI, KOSUKE MIMA, SHIGEKI NAKAGAWA, TAKATSUGU ISHIMOTO, \\ KEISUKE MIYAKE, NAOMI YOKOYAMA, TAKATOSHI ISHIKO and HIDEO BABA \\ Department of Gastroenterological Surgery, Graduate School of Life Sciences, \\ Kumamoto University, Kumamoto 860-8556, Japan
}

Received August 15, 2012; Accepted October 22, 2012

DOI: $10.3892 /$ or.2012.2162

\begin{abstract}
Cystine/glutamic acid transporter (xCT) plays a role in tumor progression by regulating the redox status in several types of cancers. To demonstrate the importance of $\mathrm{xCT}$ expression for predicting the prognosis of hepatocellular carcinoma (HCC), we analyzed xCT gene expression in 130 paired $\mathrm{HCC}$ and non-cancerous tissues. $\mathrm{xCT}$ protein expression was confirmed using $7 \mathrm{HCC}$ cell lines and samples from human subjects. xCT mRNA expression was detected in 34 (26\%) tumor tissues. Expression of $\mathrm{xCT}$ was higher in HCC tissues compared to the corresponding normal tissues according to quantitative reverse transcriptase-polymerase chain reaction findings $(\mathrm{P}<0.0001)$. Patients in the group presenting with $\mathrm{xCT}$ mRNA expression showed poorer overall and diseasefree survival than did those with an absence of $\mathrm{xCT}$ mRNA $(\mathrm{P}=0.0130$ and 0.0416 , respectively). $\mathrm{xCT}$ mRNA expression proved to be an independent factor for poor prognosis in a multivariate analysis of overall survival (hazard ratio, 1.68; 95\% CI, 1.03-2.92). We observed xCT protein expression in both the HCC cell lines and in human tissue samples. In conclusion, the findings of the present study suggest that $\mathrm{xCT}$ is useful as a predictive marker for patient prognosis and that it may be a novel therapeutic target for HCC.
\end{abstract}

\section{Introduction}

Hepatocellular carcinoma (HCC) is one of the most common gastrointestinal malignancies and the leading cause of cancer-

Correspondence to: Professor Hideo Baba, Department of Gastroenterological Surgery, Graduate School of Medical Science, Kumamoto University, 1-1-1 Honjo, Kumamoto 860-8556, Japan E-mail: hdobaba@kumamoto-u.ac.jp

Abbreviations: $\mathrm{HCC}$, hepatocellular carcinoma; $\mathrm{xCT}$, transporter responsible for amino acid transport system $\mathrm{x}_{\mathrm{c}}$; HPRT1, hypoxanthine phosphoribosyltransferase 1 ; ROS, reactive oxygen species

Key words: cystine/glutamic acid transporter, hepatocellular carcinoma, reactive oxygen species related death in East Asia and South Africa (1). At present, the first-line treatment for HCC is liver transplantation or surgical resection $(2,3)$. However, the overall survival rate after curative therapy is not satisfactory due to the highly chemoresistant nature of this tumor and frequent intrahepatic recurrence. Identification of the genes responsible for the development and progression of $\mathrm{HCC}$ and comprehension of the clinical significance of these genes are critical for adequate treatment of HCC.

Glutathione (GSH) is a tripeptide thiol consisting of glutamate, cysteine and glycine, and it plays an important role in cellular defenses against oxidative stress and toxic compounds (4). Sustenance of GSH levels in cancer cells is essential for DNA synthesis, growth, multidrug resistance, maintenance of redox status and tumor survival (5-8). System $\mathrm{x}_{\mathrm{c}}{ }^{-}$, consisting of cystine/glutamic acid transporter (xCT)/SLC7A11 and its chaperone CD98/4F2hc, functions as an exchange system for cysteine/glutamate (9). Since glutamate present in the extracellular medium can regulate cell signaling through its receptor, upregulation of $\mathrm{x}_{\mathrm{c}}{ }^{-}$in tumor cells may also be associated with increased glutamate signaling in the tumor cells themselves or in adjacent cells $(10,11)$. In contrast to normal cells, tumor cells are characterized by rapid growth and proliferation (5). This is partly due to the fact that tumor cells have cellular defenses against oxidative stress, facilitating the cell cycle and resistance to apoptosis. $\mathrm{xCT}$ is strongly associated with these systems and is therefore a potential therapeutic target $(6,10)$. We identified a CD44 variant that regulates redox status by stabilizing xCT as a pivotal marker of gastric cancer (12), yet the clinical relevance of $\mathrm{xCT}$ in $\mathrm{HCC}$ has not yet been clarified.

We subsequently investigated the clinical importance of the $\mathrm{xCT}$ gene by analyzing 130 consecutive patients with HCC as well as several HCC cell lines. We suggest that $\mathrm{xCT}$ expression is a candidate marker of HCC prognosis.

\section{Materials and methods}

Clinical tissue samples. One hundred and thirty patients (106 men and 24 women) with HCC were enrolled and underwent curative first-line surgery at the Department of Gastroenterological Surgery, Kumamoto University Hospital, between 2005 and 2010. Specimens of primary HCC and 
adjacent normal liver tissues were procured from the patients after written informed consent was obtained. This study was approved by the Human Ethics Review Committee of the Graduate School of Life Sciences, Kumamoto University (Kumamoto, Japan).

Cell lines. The Li-7 cell line was purchased from Riken BioResource Center (Osaka, Japan) and was cultured in RPMI1640 medium (Wako, Osaka, Japan). The HepG2, PLC/ PRF/5, HuH1, HuH-7, HLE and HLF cell lines were purchased from the Japanese Collection of Research Bioresources (Osaka, Japan) and the cells were cultured in Dulbecco's modified Eagle's medium (DMEM). All media were supplemented with $10 \%$ fetal bovine serum (FBS) with 100 units $/ \mathrm{ml}$ penicillin and $100 \mu \mathrm{g} / \mathrm{ml}$ streptomycin. All cultures were maintained in a $5 \% \mathrm{CO}_{2} / 95 \%$ air humidified atmosphere at $37^{\circ} \mathrm{C}$.

$R N A$ extraction and quantitative reverse transcriptase-polymerase chain reaction ( $q R T-P C R$ ). Total RNA was obtained from the frozen tissue samples and cell lines using a mirVana microRNA isolation kit (Ambion) in accordance with the manufacturer's instructions. Reverse transcription was performed with $1.0 \mu \mathrm{g}$ of total RNA as previously described (13). qRT-PCR was performed on a LightCycler 480 II using 2X PCR Master Mix and Universal Probe Library (all were from Roche Diagnostic, Tokyo, Japan). Primers were designed using the Roche webpage (http://app.roche-biochem.jp/) and the Universal Probe Library in accordance with the manufacturer's recommendations. The primers used were as follows: $\mathrm{xCT}$ forward, 5'-CCATGAACGGTGGTGTGTT-3' and reverse, 5'-GACCCT CTCGAGACGCAAC-3' and universal probe \#80; HPRT forward, 5'-TGACCTTGATTTATTTTGCATACC-3' and reverse, 5'-CGAGCAAGACGTTCAGTCCT-3' and universal probe \#73. HPRT, 18S ribosomal RNA, and GAPDH were tested as internal controls (14); HPRT proved to be the most suitable reference gene. For amplification, an initial denaturation at $95^{\circ} \mathrm{C}$ for $10 \mathrm{~min}$ was followed by $15 \mathrm{sec}$ at $95^{\circ} \mathrm{C}, 15 \mathrm{sec}$ at $60^{\circ} \mathrm{C}$ and $13 \mathrm{sec}$ at $72^{\circ} \mathrm{C}$. All experiments were performed twice to confirm reproducibility.

Western blotting. Cells were lysed in a cell lysis buffer containing $25 \mathrm{mM}$ Tris (pH 7.4), $100 \mathrm{mM} \mathrm{NaCl}$, and $1 \%$ Tween20. Equal amounts of protein were loaded onto $10 \%$ gels and separated by SDS-PAGE. Resolved proteins were transferred to polyvinylidene fluoride (PVDF) membranes (Bio-Rad), blocked with $5 \%$ low-fat dry milk in TBS-T $(25 \mathrm{mM}$ Tris $\mathrm{pH} 7.4,125 \mathrm{mM} \mathrm{NaCl}, 0.4 \%$ Tween-20) for $1 \mathrm{~h}$ at room temperature and incubated with the primary antibody overnight at $4^{\circ} \mathrm{C}$. The primary antibody, mouse monoclonal xCT antibody (KE021; TransGene Inc., Hyogo, Japan), was used at a dilution of 1:1,000. Blots were extensively washed with TBS-T and incubated for $1 \mathrm{~h}$ at room temperature with HRP-conjugated secondary antibody (Santa Cruz Biotechnology, Santa Cruz, CA, USA) diluted 1:2,000 in TBS-T. The membranes were washed and visualized using a chemiluminescence detection reagent kit (ECL Plus; GE Healthcare Corp.).

Immunofluorescence staining. Approximately $6-\mu \mathrm{m}$ cryostat sections of $\mathrm{HCC}$ were fixed for $10 \mathrm{~min}$ in $4^{\circ} \mathrm{C}$ acetone and airdried for $1 \mathrm{~h}$. Incubated cells were washed with PBS twice and then fixed for $10 \mathrm{~min}$ in $4 \%$ paraformaldehyde. Subsequently, the sections/cells were washed twice in TBS and once in TBS/ Tween-20 (0.05\%) and then incubated with $3 \%$ bovine serum albumin (BSA) (Sigma, Japan) for 15 min to block nonspecific protein binding sites. They were subsequently incubated for $1 \mathrm{~h}$ at room temperature with the primary antibody in TBS containing $1 \%$ BSA. The primary antibody, mouse monoclonal $\mathrm{xCT}$ antibody, was used at a dilution of 1:25. Samples were incubated for $1 \mathrm{~h}$ at room temperature in the dark with the secondary antibody, goat anti-mouse IgG labeled with HiLyte Fluor ${ }^{\mathrm{TM}} 555$ (Anaspec Inc., San Jose, CA, USA), in TBS containing 1\% BSA. The mounting reagent was applied using ProLong Gold including 4',6-diamidino-2-phenylindole (Invitrogen, Japan). For negative controls, a mouse IgG (Dako Co., Japan) was used instead of the primary antibody. Images were obtained with a FV300 fluorescence microscope (Olympus, Japan).

Statistical analysis. Statistical analyses were performed using JMP ver. 8.0 (SAS Institute, Cary, NC, USA). Values are expressed as the means \pm SD. Differences between groups were calculated by the Wilcoxon test. $\mathrm{P}<0.05$ was defined as indicative of a statistically significant difference.

\section{Results}

Expression of xCT in clinical tissue specimens and clinicopathological characteristics. We performed a qRT-PCR analysis with the primary HCC specimens. XCT expression was calculated by $\mathrm{xCT} /$ hypoxanthine phosphoribosyltransferase 1 (HPRT1) expression. For the clinicopathological evaluation, patients were divided into 2 groups based on expression status. The expression value of xCT was detectable in 34 (26.1\%) tumor tissues. Clinicopathological factors related to the $\mathrm{xCT}$ expression status of the 130 patients are summarized in Table I. xCT expression was not correlated with any of the clinicopathological factors.

Relationship between $x C T$ expression and prognosis. $\mathrm{xCT}$ mRNA expression was higher in HCC tissues than in the corresponding normal tissues according to qRT-PCR analysis $(\mathrm{P}<0.0001$, Fig. 1A). The relationship between each of the clinicopathological factors and prognosis was analyzed by univariate analyses (Table II). The data indicated that poor prognosis in HCC patients was correlated with a tumor diameter of $>38 \mathrm{~mm}$, multiple tumors, positive vascular invasion and positive $\mathrm{xCT}$ expression. Patients in the $\mathrm{xCT}$ mRNA present group had poorer overall and disease-free survival than did those in the $\mathrm{xCT}$ mRNA absent group $(\mathrm{P}=0.0130$ and 0.0416 , respectively) (Fig. 1B and C). The presence of $\mathrm{xCT}$ mRNA expression proved to be the only poor prognostic factor in a multivariate analysis of overall survival (Table III).

Expression of $x C T$ protein. All of the cell lines expressed $\mathrm{xCT}$ mRNA (Fig. 2A), which corresponded with the expression of $\mathrm{xCT}$ protein (Fig. 2B). The representative immunohistochemical xCT staining patterns are shown in Fig. 2; membranous expression of $\mathrm{xCT}$ was confirmed in both the cell lines (Fig. 2C) and the tissues from HCC patients (Fig. 2D and E). One of the 8 randomly selected patients had XCT protein staining of the tumor cell membrane but not in the non-tumor 
Table I. xCT expression and clinicopathological characteristics of the HCC patients.

\begin{tabular}{|c|c|c|c|c|}
\hline \multirow[b]{2}{*}{ Clinicopathological factors } & \multirow[b]{2}{*}{$\mathrm{n}$} & \multicolumn{2}{|c|}{$\mathrm{xCT}$ expression } & \multirow[b]{2}{*}{ P-value } \\
\hline & & High & Low & \\
\hline \multicolumn{5}{|l|}{ Age (years) } \\
\hline$<66$ & 62 & 12 & 50 & 0.0921 \\
\hline$\geq 66$ & 68 & 22 & 46 & \\
\hline \multicolumn{5}{|l|}{ Gender } \\
\hline Male & 106 & 28 & 78 & 0.8867 \\
\hline Female & 24 & 6 & 18 & \\
\hline \multicolumn{5}{|l|}{$\mathrm{AFP}^{\mathrm{b}}$} \\
\hline$<20$ & 74 & 20 & 54 & 0.7945 \\
\hline$\geq 20$ & 56 & 14 & 42 & \\
\hline \multicolumn{5}{|l|}{ PIVKAII $^{\mathrm{a}}$} \\
\hline$<69$ & 61 & 12 & 49 & 0.1138 \\
\hline$\geq 69$ & 69 & 22 & 47 & \\
\hline \multicolumn{5}{|l|}{ Tumor diameter $(\mathrm{mm})^{\mathrm{a}}$} \\
\hline$<38$ & 63 & 12 & 51 & 0.0738 \\
\hline$\geq 38$ & 67 & 22 & 45 & \\
\hline \multicolumn{5}{|l|}{ Tumor number } \\
\hline Solitary & 97 & 25 & 72 & 0.8655 \\
\hline Multiple & 33 & 9 & 24 & \\
\hline \multicolumn{5}{|l|}{ Differentiation } \\
\hline Well/Mod & 107 & 26 & 81 & 0.2993 \\
\hline Poor & 23 & 8 & 15 & \\
\hline \multicolumn{5}{|l|}{ Vascular invasion $^{\mathrm{c}}$} \\
\hline Negative & 72 & 17 & 55 & 0.4623 \\
\hline Positive & 58 & 17 & 41 & \\
\hline \multicolumn{5}{|l|}{$\mathrm{HCV}-\mathrm{Ab}$} \\
\hline Negative & 72 & 21 & 51 & 0.3838 \\
\hline Positive & 58 & 13 & 45 & \\
\hline \multicolumn{5}{|l|}{ HBs-Ag } \\
\hline Negative & 91 & 25 & 66 & 0.6013 \\
\hline Positive & 39 & 9 & 30 & \\
\hline
\end{tabular}

Well, well-differentiated hepatocellular carcinoma; Mod, moderately dif-

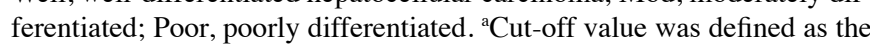
median value. ${ }^{b}$ Cut-off value was defined as the maximum normal value. 'Pathological vascular invasion. AFP, $\alpha$-fetoprotein; PIVKAII, protein induced by vitamin $\mathrm{K}$ absence/antagonist-II; HCV-Ab, hepatitis $\mathrm{C}$ virus antibody; HBs-Ag, hepatitis B virus surface antigen.

tissue. The remaining 7 patients had no $\mathrm{xCT}$ expression in normal or cancerous tissues.

\section{Discussion}

The qRT-PCR results and multivariate analysis confirmed that the presence of $\mathrm{xCT}$ mRNA expression is an independent predictive factor for poor prognosis in HCC patients. Previous reports have shown that $\mathrm{xCT}$ expression plays a functional role in tumor progression. Inhibition of the transporter function with compounds such as sulfasalazine or (S)-4-carboxyphenylglycine suppresses tumor cell growth

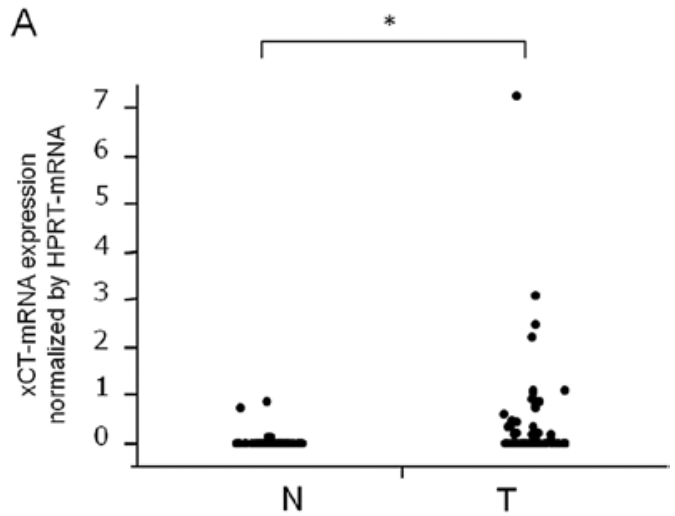

B
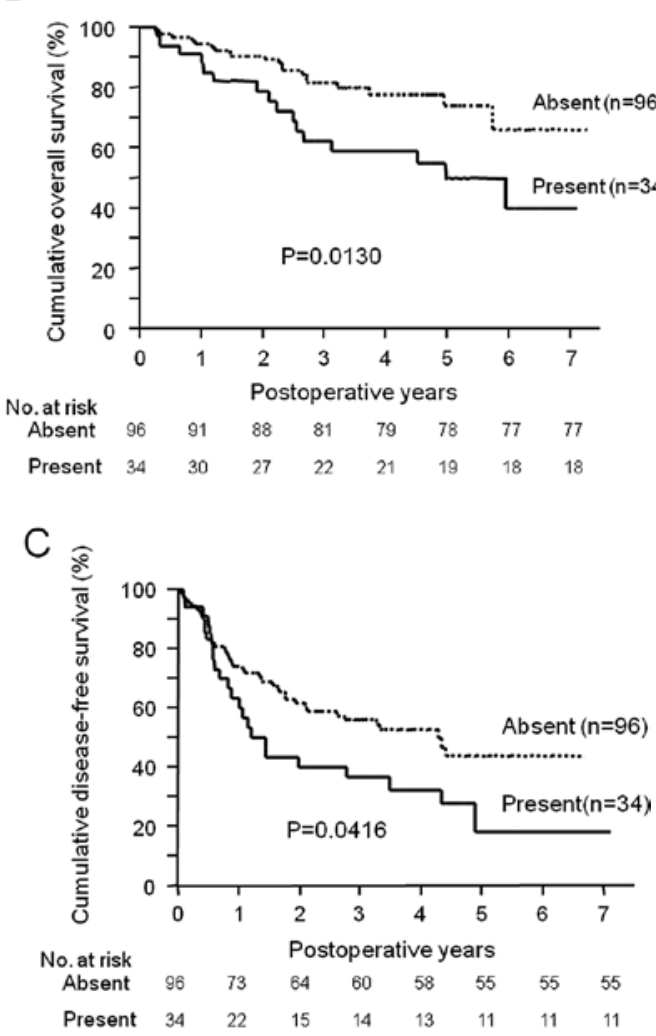

Figure 1. Clinical significance of xCT in hepatocellular carcinoma (HCC) (A) A quantitative RT-PCR analysis of xCT was performed in HCC (T) and paired normal tissue (N) specimens obtained from 130 patients. (B and C) Kaplan-Meier survival curves for patients with the presence or absence of xCT mRNA expression and its association with (B) cumulative overall survival and (C) cumulative disease-free survival.

and invasion in glioma and HCC $(5,11,15)$. Overexpression of $\mathrm{xCT}$, which results in increased $\mathrm{x}_{\mathrm{c}}{ }^{-}$activity, increases the levels and activity of the transcription factor AP-1 and promotes the cell cycle (16). In addition, $\mathrm{xCT}$ plays an important role in drug resistance in several types of tumors in vitro $(17,18)$.

xCT mRNA expression was significantly higher in tumor tissues than in normal tissues in the HCC patients. Although $\mathrm{xCT}$ expression is not specific to tumor cells and has also been observed in normal cell types such as fibroblasts (19), monocytes (20) and macrophages (21), our results indicate that functional demand for $\mathrm{xCT}$ was higher in tumor tissues 
Table II. Univariate analysis of the clinicopathological factors for overall survival in HCC patients.

\begin{tabular}{|c|c|c|c|}
\hline Clinicopathological factors & $\mathrm{n}$ & $\begin{array}{l}\text { Median survival } \\
\text { (months) }\end{array}$ & P-value \\
\hline \multicolumn{4}{|l|}{ Age $^{a}$ (years) } \\
\hline$<66$ & 62 & 43.0 & \multirow[t]{2}{*}{0.2836} \\
\hline$\geq 66$ & 68 & 37.3 & \\
\hline \multicolumn{4}{|l|}{ Gender } \\
\hline Male & 106 & 40.1 & \multirow[t]{2}{*}{0.4509} \\
\hline Female & 24 & 44.1 & \\
\hline \multicolumn{4}{|l|}{$\mathrm{AFP}^{\mathrm{b}}$} \\
\hline$<20$ & 69 & 38.7 & \multirow[t]{2}{*}{0.3001} \\
\hline$\geq 20$ & 63 & 41.1 & \\
\hline \multicolumn{4}{|l|}{ PIVKAII ${ }^{\mathrm{a}}$} \\
\hline$<69$ & 61 & 42.2 & \multirow[t]{2}{*}{0.1658} \\
\hline$\geq 69$ & 69 & 38.2 & \\
\hline \multicolumn{4}{|l|}{ Tumor diameter ${ }^{\mathrm{a}}(\mathrm{mm})$} \\
\hline$<38$ & 63 & 45.2 & \multirow[t]{2}{*}{$<0.0001$} \\
\hline$\geq 38$ & 67 & 33.1 & \\
\hline \multicolumn{4}{|l|}{ Tumor number } \\
\hline Solitary & 97 & 41.2 & \multirow[t]{2}{*}{0.0014} \\
\hline Multiple & 33 & 36.6 & \\
\hline \multicolumn{4}{|l|}{ Differentiation } \\
\hline Well/Mod & 107 & 41.7 & \multirow[t]{2}{*}{0.0913} \\
\hline Poor & 23 & 37.3 & \\
\hline \multicolumn{4}{|l|}{ Vascular invasion $^{\mathrm{c}}$} \\
\hline Negative & 72 & 42.7 & \multirow[t]{2}{*}{0.0108} \\
\hline Positive & 58 & 38.1 & \\
\hline \multicolumn{4}{|l|}{$\mathrm{HCV}-\mathrm{Ab}$} \\
\hline Negative & 72 & 37.0 & \multirow[t]{2}{*}{0.5459} \\
\hline Positive & 58 & 43.8 & \\
\hline \multicolumn{4}{|l|}{ HBs-Ag } \\
\hline Negative & 91 & 42.3 & \multirow[t]{2}{*}{0.3656} \\
\hline Positive & 39 & 36.6 & \\
\hline \multicolumn{4}{|l|}{ xCT-mRNA expression } \\
\hline Negative & 96 & 41.1 & \multirow[t]{2}{*}{0.0130} \\
\hline Positive & 39 & 37.0 & \\
\hline
\end{tabular}

Well, well-differentiated hepatocellular carcinoma; Mod, moderately dif-

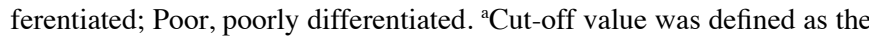
median value. ${ }^{\text {b}}$ Cut-off value was defined as the maximum normal value. 'Pathological vascular invasion. AFP, $\alpha$-fetoprotein; PIVKAII, protein induced by vitamin $\mathrm{K}$ absence/antagonist-II; $\mathrm{HCV}-\mathrm{Ab}$, hepatitis $\mathrm{C}$ virus antibody; HBs-Ag, hepatitis B virus surface antigen.

than in normal tissues. However, we did not find any correlation between $\mathrm{xCT}$ mRNA expression and clinicopathological factors. Further studies with human subjects are required with the aim of determining the relevance of $\mathrm{xCT}$ expression to functional aspects of tumors, such as reactive oxygen species (ROS) level, expression of other amino transporters and chemosensitivity.

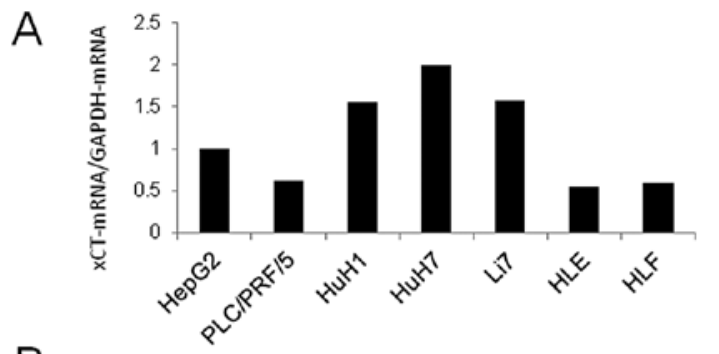

$\mathrm{B}$
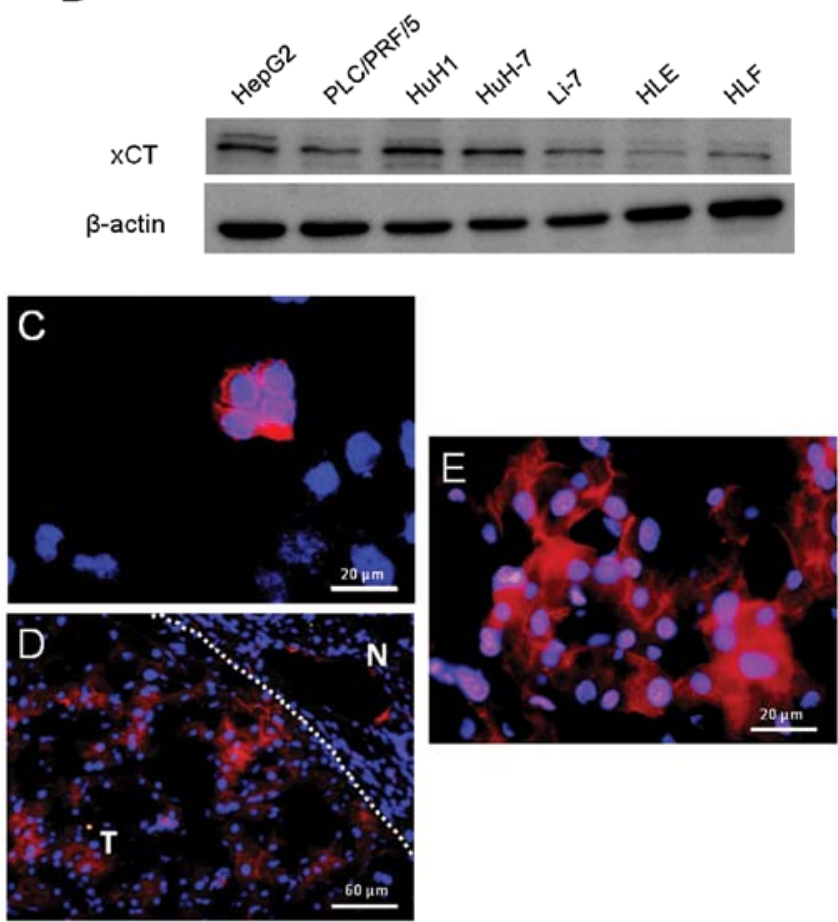

Figure 2. $\mathrm{xCT}$ protein expression in $\mathrm{HCC}$ cell lines and human $\mathrm{HCC}$ tissue samples. (A) xCT mRNA expression in $7 \mathrm{HCC}$ cell lines (HepG2, PLC/ PRF/5, HuH1, HuH-7, Li7, HLE and HLF) analyzed by quantitative RT-PCR (B) $\mathrm{xCT}$ protein expression in the $7 \mathrm{HCC}$ cell lines analyzed by western blotting. $\mathrm{xCT}$ expression in (C) HuH1 cells and in (D and E) human tissue specimens (sample no. 165) assessed by immunofluorescence staining. $\mathrm{T}$, tumor tissue; N, normal tissue. Magnification, x200 in D, magnification, $\mathrm{x} 600$ in $\mathrm{E}$.

Table III. Cox proportional hazards model for overall survival of the HCC patients.

\begin{tabular}{lcc}
\hline $\begin{array}{l}\text { Clinicopathological } \\
\text { factor }\end{array}$ & P-value & Risk ratio (95\% CI) \\
\hline High xCT expression & 0.0390 & $1.684(1.026-2.915)$ \\
Multiple tumors & 0.1034 & $1.558(0.917-2.807)$ \\
Tumor diameter $\geq 38 \mathrm{~mm}$ & 0.2398 & $1.303(0.839-2.048)$ \\
Vascular invasion, positive & 0.9867 & $1.004(0.641-1.553)$ \\
\hline
\end{tabular}

CI, confidence interval.

We attempted to confirm the localization of $\mathrm{xCT}$ in the tumor cell membrane since $\mathrm{xCT}$ is believed to function only in the form of a membranous protein and since few reports have found $\mathrm{xCT}$ expression on the tumor cell membrane $(10,12)$. We confirmed the localization of the $\mathrm{xCT}$ protein using frozen 
HCC human tissues as well as HCC cell lines. Positive xCT expression was much higher in the HCC cell lines than in the human tissue samples as the cell lines were incubated with cysteine and not cystine, resulting in xCT upregulation (22).

Sulfasalazine is a potent $\mathrm{xCT}$ inhibitor and has been used for the clinical treatment of inflammatory bowel disease and rheumatoid arthritis (23); it has been shown to arrest growth via cystine starvation in various types of cancer cells, including lymphoma, prostate cancer, HCC and breast cancer $(6,15,24,25)$. Guo et al (15) demonstrated that xCT dysfunction increased intracellular ROS levels, resulting in the autophagic death of HCC cells. Only a few of our patients with HCC showed high $\mathrm{xCT}$ expression in this study and these patients could be candidates for XCT-targeted therapy.

In conclusion, the present study suggests that $\mathrm{xCT}$ is useful as a predictive marker for patient prognosis and may be a novel therapeutic target for $\mathrm{HCC}$. We expect that the results of this study will aid in the selection of patients and in customizing therapy targeting $\mathrm{xCT}$.

\section{References}

1. Siegel R, Naishadham D and Jemal A: Cancer statistics. CA Cancer J Clin 62: 10-29, 2012.

2. Carr BI: Hepatocellular carcinoma: current management and future trends. Gastroenterology 127 (Suppl 1): S218-S224, 2004.

3. Kassahun WT, Fangmann J, Harms J, et al: Liver resection and transplantation in the management of hepatocellular carcinoma: a review. Exp Clin Transplant 4: 549-558, 2006.

4. Griffith OW: Biologic and pharmacologic regulation of mammalian glutathione synthesis. Free Radic Biol Med 27: 922-935, 1999

5. Chung WJ, Lyons SA, Nelson GM, et al: Inhibition of cystine uptake disrupts the growth of primary brain tumors. J Neurosci 25: 7101-7110, 2005

6. Doxsee DW, Gout PW, Kurita T, et al: Sulfasalazine-induced cystine starvation: potential use for prostate cancer therapy. Prostate 67: 162-171, 2007

7. Gout PW, Kang YJ, Buckley DJ, et al: Increased cystine uptake capability associated with malignant progression of $\mathrm{Nb} 2$ lymphoma cells. Leukemia 11: 1329-1337, 1997.

8. Bannai $\mathrm{S}$ and Tateishi N: Role of membrane transport in metabolism and function of glutathione in mammals. J Membr Biol 89: 1-8, 1986.

9. Verrey F, Closs EI, Wagner CA, et al: CATs and HATs: the SLC7 family of amino acid transporters. Pflugers Arch 447: 532-542, 2004.

10. Lo M, Wang YZ and Gout PW: The $\mathrm{x}_{\mathrm{c}}{ }^{-}$cystine/glutamate antiporter: a potential target for therapy of cancer and other diseases. J Cell Physiol 215: 593-602, 2008.
11. Lyons SA, Chung WJ, Weaver AK, et al: Autocrine glutamate signaling promotes glioma cell invasion. Cancer Res 67: 9463$9471,2007$.

12. Ishimoto T, Nagano O, Yae T, et al: CD44 variant regulates redox status in cancer cells by stabilizing the XCT subunit of system $\mathrm{x}_{\mathrm{c}}{ }^{-}$and thereby promotes tumor growth. Cancer Cell 19: 387-400, 2011.

13. Okabe H, Beppu T, Ueda M, et al: Identification of CXCL5/ ENA-78 as a factor involved in the interaction between cholangiocarcinoma cells and cancer-associated fibroblasts. Int $\mathbf{J}$ Cancer: February 15, 2012 (Epub ahead of print).

14. Fu LY, Jia HL, Dong QZ, et al: Suitable reference genes for real-time PCR in human HBV-related hepatocellular carcinoma with different clinical prognoses. BMC Cancer 9: 49, 2009.

15. Guo W, Zhao Y, Zhang Z, et al: Disruption of xCT inhibits cell growth via the ROS/autophagy pathway in hepatocellular carcinoma. Cancer Lett 312: 55-61, 2011.

16. Lastro M, Kourtidis A, Farley K and Conklin DS: xCT expression reduces the early cell cycle requirement for calcium signaling. Cell Signal 20: 390-399, 2008.

17. Huang Y, Dai Z, Barbacioru C and Sadee W: Cystine-glutamate transporter SLC7A11 in cancer chemosensitivity and chemoresistance. Cancer Res 65: 7446-7454, 2005.

18. Okuno S, Sato H, Kuriyama-Matsumura K, et al: Role of cystine transport in intracellular glutathione level and cisplatin resistance in human ovarian cancer cell lines. Br J Cancer 88: 951-956, 2003.

19. Bannai S: Exchange of cystine and glutamate across plasma membrane of human fibroblasts. J Biol Chem 261: 2256-2263, 1986.

20. Eck HP and Droge W: Influence of the extracellular glutamate concentration on the intracellular cyst(e)ine concentration in macrophages and on the capacity to release cysteine. Biol Chem Hoppe Seyler 370: 109-113, 1989.

21. Rimaniol AC, Mialocq P, Clayette P, et al: Role of glutamate transporters in the regulation of glutathione levels in human macrophages. Am J Physiol Cell Physiol 281: C1964-C1970, 2001.

22. Ganapathy V, Thangaraju M and Prasad PD: Nutrient transporters in cancer: relevance to Warburg hypothesis and beyond. Pharmacol Ther 121: 29-40, 2009.

23. Capell HA, Madhok R, Porter DR, et al: Combination therapy with sulfasalazine and methotrexate is more effective than either drug alone in patients with rheumatoid arthritis with a suboptimal response to sulfasalazine: results from the doubleblind placebo-controlled MASCOT study. Ann Rheum Dis 66: 235-241, 2007.

24. Gout PW, Buckley AR, Simms CR and Bruchovsky N: Sulfasalazine, a potent suppressor of lymphoma growth by inhibition of the $\mathrm{x}(\mathrm{c})$-cystine transporter: a new action for an old drug. Leukemia 15: 1633-1640, 2001.

25. Narang VS, Pauletti GM, Gout PW, et al: Sulfasalazine-induced reduction of glutathione levels in breast cancer cells: enhancement of growth-inhibitory activity of doxorubicin. Chemotherapy 53: 210-217, 2007. 